\title{
Diversity and distribution of Dragonfly in District Sialkot, Punjab, Pakistan
}

\author{
Burhan Hafeez ${ }^{1 *}$, Muhammad Faheem Malik ${ }^{1}$, Waqas Asghar ${ }^{1}$, Rabia \\ Shabbir ${ }^{1}$, Isba Latif ${ }^{1}$, Aqsa Jabeen ${ }^{1}$, Hira Basit ${ }^{1}$ and Farwa Ghafoor ${ }^{1}$ \\ 1. Department of Zoology, University of Gujrat, Gujrat, Punjab-Pakistan \\ *Corresponding author's email: burhanhafeez575@gmail.com \\ Citation \\ Burhan Hafeez, Muhammad Faheem Malik, Waqas Asghar, Rabia Shabbir, Isba Latif, Aqsa Jabeen, Hira Basit \\ and Farwa Ghafoor. Diversity and distribution of Dragonfly in District Sialkot, Punjab, Pakistan. Pure and Applied \\ Biology. Vol. 10, Issue 4, pp988-994. http://dx.doi.org/10.19045/bspab.2021.100103
}

\begin{tabular}{llll}
\hline \hline Received: 07/10/2020 & Revised: 18/12/2020 & Accepted: 31/12/2020 & Online First: 05/01/2021 \\
\hline \hline
\end{tabular}

\section{Abstract}

The present research was organized with the objective to explore the diversity and distribution of dragonfly (Odonata; Insecta) in district Sialkot, Punjab, Pakistan. The capturing was done during 2019 from 16 chosen localities of all four tehsils including Sialkot, Sambrial, Daska and Pasroor. Total of 185 specimens of dragonfly was captured with the help of sweep nets and handpicking. Identified specimens up to species level and then preserved. There are 10 species of dragonfly belonging to 7 genera and 2 families pinpointed from collected data. Pantala flavescens, Crocothemis erythraea, Crocothemis survilia, Neurothemis fluctuans, Acisoma panorpoids, Acisoma variegatum, Orthetrum pruinosum, Orthetrum sabina which comes under Pantala, Crocothemis, Ascisoma, Neurorothemis and Orthetrum genera of family Libellulidae. The prevailing 2 species, Anax indicus and Hemianax ephippiger come under Anax and Hemianax genera of family Aeshnidae. Family Libellulidae exceptionally commanding over family Aeshnidae. Head Marala is the most plentiful point because $12.3 \%$ of specimens were assembled and Qila Tek Singh is least plentiful point with $4.1 \%$ of total specimen assemblage. Pantala flavescens is the most bountiful species with $22.2 \%$ found nearly in all the localities and Orthetrum sabina is least bountiful species with just 3.8\%. The Simpson species index is 0.8707 which far from 0 and nearer to 1 and Shannon-Weinberg diversity index is 2.1353 representing great diversity. The species richness 0.9274 . Dragonfly is an agile flier, playing some indispensable role as a biological control agent and are good bio-indicators. After this research, it is concluded that Sialkot is rich with dragonfly diversity.

Keywords: Aeshnidae; Bioindicators; Dragonfly; Libellulidae; Sambrial; Head Marala; Pantala flavescens

\section{Introduction}

Sialkot is one of the most important agricultural district of province Punjab, Pakistan consisting of plane land having great variety in flora and fauna. Sialkot has humid-subtropical climate. Sialkot is one the district which has plane and very fertile soil therefore, it is one the agricultural and industrial city of Pakistan.

The etymology of the name of dragonflies is that it is a Greek language word "Odonto" which means tooth, as appear very sharp teeth in young odonates [1]. Dragonflies are the insects belonging to order Odonata and sub-order Anisoptera [2]. There are approximately 6000 species distributed all over the world [3]. These are fascinating creatures' having beautiful colours, changing from species to species with decorated values too [4]. Being Diurnal, can easily be seen in afternoon abundantly due to their large body size [5]. 
They are extremely efficient bioindicators for sustainability of the ecosystem as predators as well as quality detectors [6], highly sensitive to the climatic changes [7]. The changing climate all over the world has adversely affected dragonfly diversity all the world too [8]. Some species are used as biological indicators to check the quality of water whether is pure or impure water [9]. The presence of Anax junius indicates the dirty water quality whereas $L$. disjunctus shows good quality water [10].

The breeding of dragonfly mostly occurs in aquatic habitat [11]. The life cycle of dragonfly consists of three stages egg, larva and pupa occurring in aquatic ecosystems, the eggs are laid in water which eventually hatches to emerge larva which is predators in nature, this larva emerges into an adult dragonfly which is the pest of many crops and fruits [2].

Flight mechanism of the dragonfly is based upon the man's swimming mechanism with a slight difference of presence of fluid in insects which provides uplifting force to wing that facilitates flying [12]. The flight mechanism of dragonfly could be studied by mean lift coefficient quasi-steady analysis, by using this analytical technique, we can predict the force, velocity and acceleration for a free flight of any concerned species of dragonfly [13]. The corrugated arrangement of wings provides efficient support and rigidity to wings which remarkably reduces the weight of dragonfly and upheld the aerodynamic mechanism to make ease during flight [14].

Dragonflies have multiple roles in ecosystem, predators of small insect from larvae to adults and aquatic to terrestrial habitats as well as a source of food for aquatic population like frog and fishes [15]. The feeding habits in dragonfly varies according to the life stages larvae are predators of freshwater habitats [16], whereas, Adults might be pests of crops as well as predators feeding on small organisms playing important role in ecosystem sustainability [17]. As a prey, eaten by large aquatic organisms like fishes, amphibians and aquatic insects, being predators eat crop pests and mosquitoes preventing us from many endemic diseases spread by these blood-sucking organisms [18].

The most preferred breeding sites are freshwater ecosystem [19]. The reproduction is generally followed by the territory formation with minor differences from species to species [20]. For example, $O$. japonicum and $P$. flavescens species of family Libellulidae, exhibit territorial reproduction, mating without territory, however, reported [21].

\section{Materials and Methods}

To determine the diversity, distribution and abundance of dragonfly, sampling surveys conducted form 2018-19 at Sialkot, Punjab, Pakistan. Sixteen localities were selected for collection keeping in mind the habitat of dragonfly throughout the district. Kamal Pur, Sahowala, Dhanawali, Khambranwala, Kulluwal, Head Marala, Jurian Kalan, Kaporowali, Ganjianwali, Ghuinke, Motra, Badiana, Jamke, Baddoke, Adamke and Qila Tek Singh as indicated in the map (Figure 1).

\section{Collection method}

The visits have been made to the selected localities at regular intervals. There were two visits in a month having a fortnight gap to visit each locality. All the visits were made from 11 AM to 4 PM because dragonflies are diurnal, their activity peak lies in these hours and abundantly available in this time. All the collection has done with the help sweep nets and handpicking method. Glass jars require for storage of specimens to be collected. So, I used sweep net having circle diameter about 3.5 feet with 5 feet long handle.

\section{Killing of specimens}

Specimens after collection put into a jar having few drops of acetone, keep on watching until they are dead. When the specimens become dead, take them back into the collecting jars. Perform this practice as soon as possible because this would decrease the chance of escaping the active specimen. 


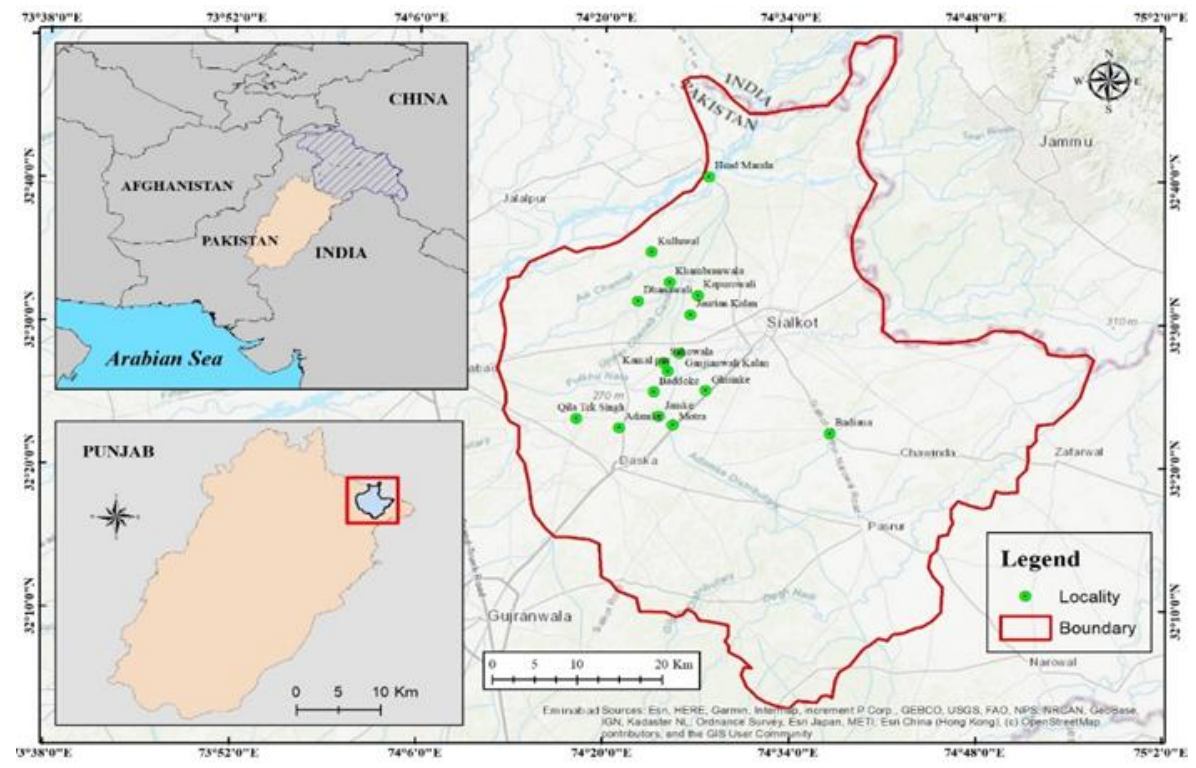

Figure 1. Map Showing the Selected Sites from District Sialkot, Punjab, Pakistan

\section{Preservation and pinning of specimens}

The most common preservative used for the preservation of dragonfly is acetone because it is easily available and more acidic than alcohol which digests proteins rapidly as well as pests of dragonfly. The killed specimens placed in a jars for more than After 15 to 16 hours, removed the specimens from acetone and let it dry for 50 55 mint. When the specimens became fully dried they were pinned on dorsal side on a thermocol sheet for long time storage. Coopex powder was poured on pinned insects to repel ants otherwise they would decompose them.

\section{Identification of specimens}

The identification was done in the Departmental lab of Zoology, University of Gujrat. All the preserved specimens were identified up to species level by using different parameters of morphology including shape, body colour, wing size and wing structure. After identification, the specimens were tagged according to the identification. The identification was done by using a stereomicroscope present in the departmental lab and different taxonomic keys.

\section{Statistical analysis}

Different indices used for determination of biodiversity were applied on collected data to check diversity, distribution, species richness and evenness like Shanon index and Simpson index. Species richness was determined by using Margalef's richness index and evenness calculated by Simpson index. The advantage of Microsoft excel was taken to calculate and analyse data statistically.

\section{Results and Discussion}

During recent research, about 195 specimens captured from marked localities in district Sialkot, Punjab, Pakistan. Population density fluctuates with seasons. This diversity was compared with other regions of country like Potohar Plateau [22]. This experiment documents and reports 10 dragonfly species belonging to 7 genera and 2 families [23]. During winter season, population density is very low while during summer season higher population density observed. It means these are temperature depending creatures. Higher temperature favours their abundance whereas as lower temperature reduces their abundance. Moreover, the vegetation of a particular area also highly influences the abundance and biodiversity of dragonflies [24]. The detail of species is given in (Table 1). 
Table 1. Diagnostic features of species

\begin{tabular}{|c|c|c|c|}
\hline Species & Diagnostic Features & Size $(\mathrm{mm})$ & Picture \\
\hline $\begin{array}{l}\text { Pantala } \\
\text { flavescense }\end{array}$ & $\begin{array}{l}\text { Medium size species having pale yellow } \\
\text { colour appearance. Forewing and hindwing } \\
\text { are almost of same size bearing pterostigma on } \\
\text { upper side of both fore and hind wings. }\end{array}$ & $\begin{array}{l}\text { Forewing } \\
24.6 \\
\text { Hindwing } \\
21.7 \\
\text { Abdomen } \\
16.9 \\
\end{array}$ & \\
\hline $\begin{array}{l}\text { Crocothemis } \\
\text { survilia }\end{array}$ & $\begin{array}{l}\text { more or less resembles that of pantala genus } \\
\text { having yellowish appearance but the } \\
\text { difference between these two is the dark } \\
\text { yellow colour spots near the base of both } \\
\text { fore and hind wings. However, } \\
\text { pterostigma present on upper side of both } \\
\text { wings pair. }\end{array}$ & $\begin{array}{l}\text { FW } 31.4 \\
\text { HW } 28.6 \\
\text { A } 23.7\end{array}$ & \\
\hline $\begin{array}{l}\text { Crocothemis } \\
\text { erythraea }\end{array}$ & $\begin{array}{l}\text { Similar to } C \text {. survilia but differ in } \\
\text { abdominal color with red in } C \text {. erythraea }\end{array}$ & $\begin{array}{l}\text { FW } 31.1 \\
\text { HW } 28.2 \\
\text { A } 23.3\end{array}$ & \\
\hline $\begin{array}{l}\text { Neurothemis } \\
\text { fluctuans }\end{array}$ & $\begin{array}{l}\text { Medium-sized body, both pairs of wings } \\
\text { have } 2 / 3^{\text {rd }} \text { portion with yellow colour with } \\
\text { dark yellow abdominal. }\end{array}$ & $\begin{array}{l}\text { FW } 24.9 \\
\text { HW } 24.8 \\
\text { A } 17.8\end{array}$ & \\
\hline $\begin{array}{l}\text { Orthetrum } \\
\text { sabina }\end{array}$ & Medium to large body size, hindwings are circul & $\begin{array}{l}\text { FW 33.5 } \\
\text { HW } 31.5 \\
\text { A } 28.9\end{array}$ & \\
\hline $\begin{array}{l}\text { Orthetrum } \\
\text { pruinosum } \\
\text { neglectum }\end{array}$ & $\begin{array}{l}\text { The body is average to large size. Head dark } \\
\text { coloured, abdomen red coloured and both } \\
\text { pairs of wings have sterostigma. }\end{array}$ & $\begin{array}{l}\text { FW } 33.6 \\
\text { HW } 31.5 \\
\text { A } 28.7\end{array}$ & \\
\hline $\begin{array}{l}\text { Acisoma } \\
\text { panorpoides }\end{array}$ & $\begin{array}{l}\text { Small-sized, blue head with blue stripes on } \\
\text { abdomen. Abdomen becomes suddenly } \\
\text { sharp after } 6^{\text {th }} \text { abdominal segment. }\end{array}$ & $\begin{array}{l}\text { FW } 22.5 \\
\text { HW } 21.6 \\
\text { A } 17.9\end{array}$ & \\
\hline $\begin{array}{l}\text { Acisoma } \\
\text { variegatum }\end{array}$ & $\begin{array}{l}\text { Small-sized, brass green head with brass } \\
\text { green strips on abdomen. Abdomen } \\
\text { becomes suddenly sharp after } 6^{\text {th }} \\
\text { abdominal segment, have beautiful } \\
\text { appearance. }\end{array}$ & $\begin{array}{l}\text { FW } 22.4 \\
\text { HW } 21.7 \\
\text { A } 18.2\end{array}$ & \\
\hline Anax indicus & $\begin{array}{l}\text { Large size with orange colour } \\
\text { abdomen, forewings slightly larger than } \\
\text { hind wings }\end{array}$ & $\begin{array}{l}\text { FW } 52.5 \\
\text { HW } 49.7 \\
\text { A } 60.5\end{array}$ & \\
\hline $\begin{array}{l}\text { Hemianax } \\
\text { ephippiger }\end{array}$ & Large size, dark yellow coloured body. & $\begin{array}{l}\text { FW } 48.7 \\
\text { HW } 46.6 \\
\text { A } 45.5\end{array}$ & \\
\hline
\end{tabular}

FW: Forewing HW: Hindwing A: Abdomen

The biodiversity of population was calculated by different appropriate indices like Simpson's index, Shannon-Weinberg index, Fisher and Menhinick. The calculations show evenness (0.9273) and diversity in species (2.1353). The Simpson species index is 0.8707 which far from 0 and nearer to 1 pointing higher species diversity 
in this area. The Shannon-Weinberg diversity index is 2.1353 representing great diversity. The species richness 0.9274 .

From these 10 species, Pantala flavescens appeared to be the most abundant species with highest percentage $(22.2 \%)$ and Orthetrum sabine seems to be the lowest abundant species with lowest percentage $(3.8 \%)$. All other species have abundant in between these two. Family libellulidae is found to be the most abundant and dominant in district Sialkot, Punjab, Pakistan. This observation has been reported many times by many scientists in the past [25].

From the selected localities Head Marala was most abundant site of the collection with greater percentage $(12.3 \%)$ suggesting vegetative and water-rich area and Qila Tek Singh being lowest abundant having lowest percentage $(4.1 \%)$. The remaining localities have fluctuation in between these localities. The abundance of dragonflies fluctuates with fluctuation in the environment. The abundance of dragonflies in spring is much lower than in summer [26]. The most favourable temperature for breeding of dragonflies lies in between $35-40^{\circ} \mathrm{C}$. The abundance during spring is $22.1 \%$ which is much lesser than abundance during summer season ranging up to $77.9 \%$ like the following (Figure $2 \& 3$ ) showed.

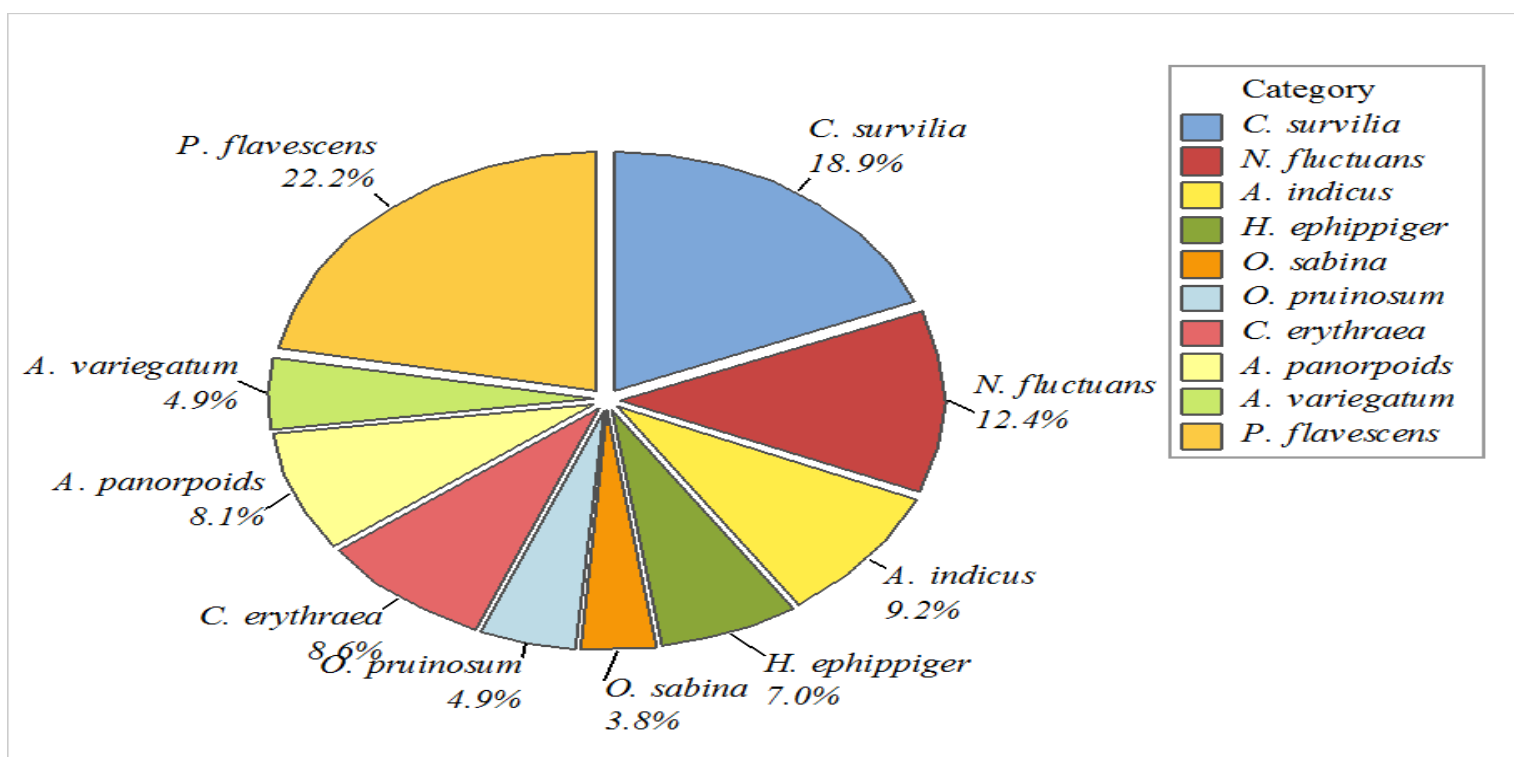

Figure 2. Abundance of different species

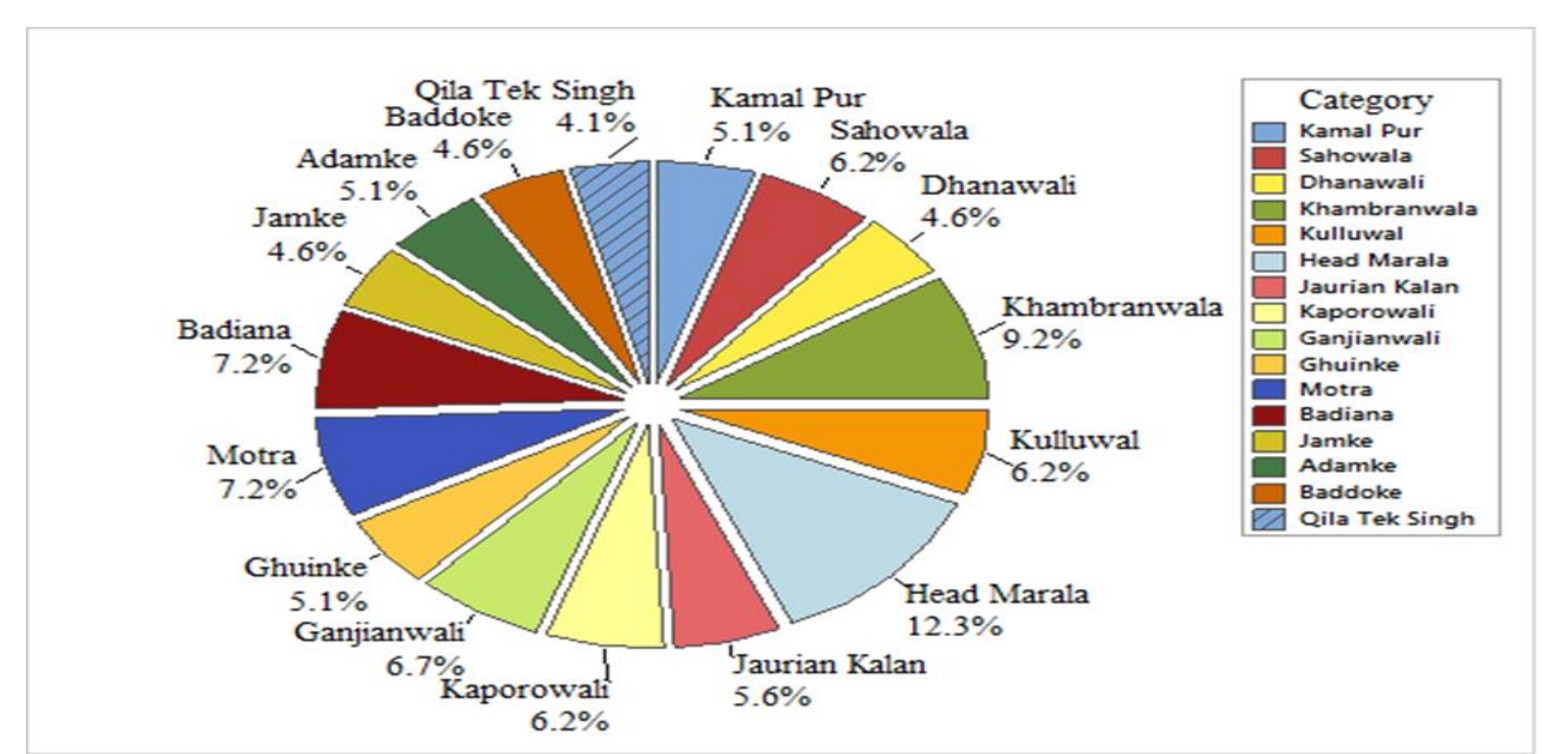

Figure 3. Abundance with reference to locality 


\section{Conclusion and Recommendations}

After this research, it is recommended that the presence of the reported species should be confirmed in future research. The contamination of water must be prevented as it is harmful to aquatic organisms as well as for human beings, leading to diverse diseases. Some preventive measures should be taken to protect the habitat of dragonflies. Check and balance in population should be maintained to sustain ecosystem because their larger population can cause economic loss as they are pests of some crops. Being a biological indicator of the ecosystem, their efficient role in sustainability of the ecosystem should be studied. Being predators, their efficient role in biological control should be thoroughly studied in IPM.

\section{Authors' contributions}

Conceived and designed the experiments: B Hafeez \& MF Malik, Performed the experiments: B Hafeez, I Latif \& A Jabeen, Analyzed the data: W Asghar \& R Shabbir, Contributed materials/ analysis/ tools: $\mathrm{H}$ Basit \& F Ghafoor, Wrote the paper: B Hafeez.

\section{References}

1. Satpathi CR (2017). A Treatise on Dragonflies (Order: Odonata, Class: Insecta) of rice ecosystems in Eastern India. Wor Sci News 86(2): 67-133.

2. Subramanian KA (2005). Dragonflies and damselflies of Peninsular India-A field guide. E-Book of Project Lifescape. Centre for Ecological Sciences, Indian Institute of Science and Indian Academy of Sciences, Bangalore, India, 118.

3. Acharjee B \& Karzee, L (2016). A Checklist of Dragonfly (Odonata: Anisoptera) Diversity in The Campus of University of Science and Technology, Meghalaya (USTM), RI Bhoi District, Meghalaya, India. $J$ of Entomol and Zool Stud 4: 124-127.

4. Perveen F (2014). Check list of first recorded dragonfly (Odonata: Anisoptera) fauna of District Lower
Dir, Khyber Pakhtunkhwa, Pakistan. Arthropods 3(2): 120.

5. Kalkman VJ, Clausnitzer V, Dijkstra KDB, Orr AG, Paulson DR \& Van Tol J (2007). Global diversity of dragonflies (Odonata) in freshwater. Freshw Anim Divers Assess 595: 351363.

6. Narender M, Ahmad SA, Pandit RS \& Wankhade V (2016). Seasonal Variations in Diversity and Abundance of Odonata at Sawanga-Vithoba Lake, India. J of Entomol 13(5): 170-178.

7. Balzan MV (2012). Associations of dragonflies (Odonata) to habitat variables within the Maltese Islands: A spatio-temporal approach. $J$ of Insect Sci 12(1).

8. Damerow J (2014). Diversity and Distribution of California Dragonflies and Other Aquatic Taxa Over the Past Century (Doctoral dissertation, UC Berkeley).

9. Jacob S \& Manju EK (2016). Potential of Odonate (dragonflies and Damselflies) Diversity as a Bioindicator of Water Quality. Inter $J$ of Sci and Res 5(7): 2033-2036.

10. Catling PM (2005). A potential for the use of dragonfly (Odonata) diversity as a bioindicator of the efficiency of sewage lagoons. The Can FieldNat 119(2): 233-236.

11. Acquah-Lamptey D, Kyerematen R \& Owusu EO (2013). Dragonflies (Odonata: Anisoptera) as tools for habitat quality assessment and monitoring. $J$ of Agric and Biodiv $\operatorname{Res} 2(8)$ : 178-182.

12. Wang ZJ (2008). Dragonfly flight. Phys Today 61(10): 74-75.

13. Wakeling JM \& Ellington CP (1997). Dragonfly flight. III. Lift and power requirements. J of Experi Biol 200(3): 583-600.

14. Jongerius SR \& Lentink D (2010). Structural analysis of a dragonfly wing. Experi Mechanics 50(9): 13231334. 
15. Combes SA, Salcedo MK, Pandit MM \& Iwasaki JM (2013). Capture success and efficiency of dragonflies pursuing different types of prey. Integrative and Comparative Biol 53(5): 787-798.

16. Kundanati L, Das P \& Pugno NM (2019). Prey capturing and feeding apparatus of dragonfly nymph. Biol Rxiv 536805.

17. Turner AM \& Chislock MF (2007). Dragonfly predators influence biomass and density of pond snails. Oecologia 153(2): 407-415.

18. Sahito HA, Bhutto SR, Kousar T, Jatoi FA, Mangrio WM, BD G \& Shah ZH (2017).

Morhphotaxanomic Characteristics of Dragonfly, Lesser Emperor, Anax parthenope (Selys, 1839) (Odonata: Aeshnidae) at Region Sukkur, Sindh. J of Adv Bot and Zool 5(2).

19. Payra A, Dash S, Mishra A, Palei H, Mishra R \& Rout S (2014). A preliminary study on Odonata (Dragonfly and Damselfly) diversity in Athagarh forest division, Odisha, India. Eplanet 12(2): 43-49.

20. Ware J, Karlsson M, Sahlén G \& Koch K (2012). Evolution of reproductive strategies in libellulid dragonflies (Odonata: Anisoptera). Org Divers \& Evo 12(3): 313-323.
21. Sharma G (2017). Studies on the Reproductive Behaviour of Dragonfly, Pantala flavescens (Fabricius, 1798) (Odonata: Insecta: Arthropoda) in Aravalli Range and Desert Ecosystem of Rajasthan, India. Biol Bull 3(1): 6773.

22. Chaudhry MT, Ul Mohsin A, Bhatti MI, Javed RA \& Abbas G (2013). First record of Anaciaeshna jaspidea and Epophthalmia vittata vittata (Odonata: Anisoptera) from Pakistan. Iran $J$ of $\mathrm{Sci}$ and Tech (Sci) 37(4): 445-448.

23. New T (2004). A guide to the dragonflies of Borneo. Their identification and biology. J of Inse Cons 7: 249-250.

24. Din AU, Zia A, Bhatti AR \& Khan MN (2013). Odonata Naiads of Potohar Plateau, Punjab, Pakistan. Pak J of Zool 45(3): 3645.

25. Basumatary P, Adhikary D, Daimary M, Basumatary N \& Daimary A (2015). A preliminary study on the diversity of odonata in Bodoland University and its vicinity, Assam, India. Inter $J$ of Sci and Res Publi, 5(6), 1-8.

26. Acquah-Lamptey D, Kyerematen R \& Owusu EO (2013). Using Odonates as markers of the environmental health of water and its land related ecotone. Inter $J$ of Biod and Con 5(11): 761-769. 